УДК 371.2:316.614: [159.923.2]

Н. А. Ємець, к. фрілос. н., доцент, О. Є. Мельник, к. фрілос. н., доцент, Н. В. Шакун, к. фрілос. н., доцент

\title{
ОСВІТНЄ СЕРЕДОВИЩЕ ЯК ЧИННИК ГЕНДЕРНОЇ СОЦІАЛІЗАЦІЇ ОСОБИСТОСТІ
}

Актуальність теми дослідження. Сучасні виклики, які постають перед Україною на иляху розбудови демократичної держави та громадянського суспільства, вимагають розробки нових концептуальних підходів в царині гендерної соціалізації особистості.

Постановка проблеми. Недостатність теоретичного і практичного опрацювання впливу освіти на гендерну соціалізацію особистості ускладнює чітке системне бачення ії сутності.

Аналіз останніх досліджень і публікацій. Питання розробки концептуальних основ соиіалізації особистості в освітньому середовищі розглядалися такими вітчизняними та зарубіжними дослідниками, як В. Андерсон, М. Кіммел та ін. (теоретичні основи), В. Кравець, Т. Говорун, О. Кікінежді (прикладні аспекти), О. Вороніна, Т. Голованова, Н. Світайло, Т. Марценюк та ін. (концепція гендерного підходу).

Виділення недосліджених частин загальної проблеми. Вплив освітньої сфрери на процес формування та реалізації гендерночутливої особисті є недостатньо вивчений.

Постановка завдання. Визначити засади та принципи створення освітнього середовища, сприятливого для гендерної соціалізації особистості.

Виклад основного матеріалу. Розглядається роль освітнього середовища в процесі соціального конструювання статі як елемента культури і соціальної стратифрікації та налагодженні міжособистісної взаємодії, що контролюється суспільством і через яку відтворюється уявлення про чоловіче і жіноче як категорії соціального порядку.

Висновки. Становлення соціально активної особистості з високим рівнем сфрормованості гендерної культури можливе за умови трансформації освітнього процесу в напрямку нейтралізації гендерних стереотипів та розширення соціального простору для всебічного розвитку особистості.

Ключові слова: освіта; освітнє середовище; гендерний підхід; гендерна соціалізація.

N. A. Yemets, Candidate of Philosophical Sciences, Assistant Professor,

O. Y. Melnyk, Candidate of Philosophical Sciences, Assistant Professor,

N. V. Shakun, Candidate of Philosophical Sciences, Assistant Professor

\section{EDUCATIONAL ENVIRONMENT AS A FACTOR OF GENDER SOCIALIZATION OF PERSONALITY}

Urgency of the research. Modern challenges that Ukraine faces on the road to building a democratic state and a civil society require the development of new conceptual approaches in the area of gender socialization of an individual.

Target setting. The lack of theoretical and practical works on the influence of education on the gender socialization of an individual complicates the clear systemic vision of its essence.

Actual scientific researches and issues analysis. Questions of the development of the conceptual foundations of socialization of an individual in the educational environment were considered by domestic and foreign researchers such as V. Anderson, M. Kimmel, and others. (theoretical bases), V. Kravets, T. Govorun, O. Kikinezhdy (applied aspects), O. Voronin, T. Golovanov, N. Svitilyo and others. (Gender Concept).

Uninvestigated parts of general matters defining. The influence of the educational sphere on the process of the formation of a gender-sensitive individual is not sufficiently studied. 
The research objective. To define the principles of creating an educational environment conducive to gender socialization of an individual.

The statement of basic materials. The role of the educational environment in the process of social construction of the gender as an element of culture and social stratification and the establishment of interpersonal interaction, controlled by society and reproducing the idea of male and female as a category of social order.

Conclusions. The formation of a socially active person with a high level of formation of a gender culture is possible provided that the educational process is transformed in the direction of neutralizing gender stereotypes and the expansion of the social space for the comprehensive development of the individual.

Keywords: education; educational environment; gender approach; gender socialization.

$$
\text { DOI: 10.25140/2412-1185-2018-2(12)-23-29 }
$$

Актуальність теми дослідження. Нині Україна зіштовхнулася з цілою низкою проблем, які вимагають невідкладного вирішення на шляху розбудови демократичної держави та громадянського суспільства. Серед них - подолання всіх видів дискримінації і створення умов для повноцінної реалізації особистості.

Наявний суспільний запит на гендерні дослідження соціальної ролі освіти зумовлений тим, що гендерна нерівність визнана сучасним світовим співтовариством однією з найбільш поширених у світі форм порушення прав людини. Показово також те, що дотримання гендерного паритету визначено однією з головних цілей розвитку тисячоліття, прийнятих ОООН у 2000 році.

Постановка проблеми. Теоретична і практична розробка теми впливу освіти на гендерну соціалізацію особистості $є$ питанням першочергової ваги, оскільки сучасна система освіти значною мірою орієнтована на культивування традиційних стереотипів у ставленні до чоловіків та жінок, що сприяє посиленню гендерної асиметрії та ієрархії в суспільстві. О.Ярська-Смірнова звертає увагу на те, що «саме в навчальних закладах ми дізнаємося про те, хто важливий для суспільства, а хто - ні, хто вплинув на історію, на розвиток науки, мистецтва, літератури і соціальної організації, які можливості існують для різних людей; водночас організація освіти і пануючі в ній гендерні ролі диктують жіночі й чоловічі статусні позиції» [1, с.298].

Аналіз останніх досліджень та публікацій. Теоретичну базу гендерних досліджень проблеми соціалізації особистості сформували такі зарубіжні науковці, як В. Андерсон, Дж. Анкер, Т. Бек, Т. Веблен, Д. Вулфорд, К. Делфрі, М. Кіммел, Дж. Скотт та ін. Прикладні аспекти гендерного підходу ґрунтовно проаналізували В. Кравець, Т. Говорун, О. Кікінежді та ін. Концепцію гендерного підходу в освіті розробляють О. Вороніна, Т. Голованова, Т. Дороніна, Т. Ісаєва, Т. Кліменкова, І. Кльоцина, О. Луценко, Н. Монахова, Г. Омельченко, О. Петренко, Н. Світайло, Л. Шалаєва, О. Шнирова, Л.Штильова та ін.

Виділення недосліджених частин загальної проблеми. Систематична розробка гендерного підходу в освіті в Україні починається з 2000-х років. Суттєвий вплив на вирішення гендерних питань, в тому числі й засобами освіти, здійснюють міжнародні організації - ООН, Ради Європи та ін. Логічним кроком у ствердженні важливої ролі освіти для соціальної політики та гуманітарного розвитку держави стала «Стратегія впровадження гендерної рівності у сфері освіти «Освіта: гендерний вимір - 2021», яка була розроблена Міністерством освіти і науки у співпраці з найкращими українськими та міжнародними експертами. Разом з тим, сутнісні характеристики освітнього середовища з урахуванням реалізації принципу гендерної рівності та його вплив на конструювання гендерної ідентичності особистості залишаються маловивченими, що, власне, і робить їх актуальними у якості предмета дослідження.

Постановка завдання. Розглянути роль освітнього середовища в процесі гендерної соціалізації особистості.

Виклад основного матеріалу. Аналіз соціального впливу освіти, на нашу думку, необхідно здійснювати на мега-, макро- та на макрорівні. Перший (мегарівень) визначає роль освіти як дієвого механізму подолання нерівності, дискримінації людини у глобальному світопросторі. На макрорівні, освіта як соціальний інститут, стає потужним чинником суспільних перетворень, здатним сприяти розв'язанню важливих соціальних проблем та запобігати виникненню суспіль- 
них протиріч і конфліктів. Мікрорівень функціонування освітнього середовища забезпечує самоіндентифікацію особистості, створює умови для засвоєння нею елементів культури, соціальних норм і цінностей, на основі яких формуються соціально значущі риси особистості.

Невід'ємною складовою втілення принципів рівності та недискримінації у вітчизняну освіту є впровадження гендерного підходу як механізму досягнення гендерної рівності та утвердження рівних можливостей для самореалізації кожної особистості. Гендерний підхід базується на уявленні про соціальну конструкцію статі як елемента культури і соціальної стратифікації. В його контексті система взаємовідносин жінок і чоловіків. що складаються у суспільстві та змінюються, розглядається з урахуванням культурних традицій, соціальних норм, національних, релігійних, соціально-економічних та політичних особливостей. Гендерний підхід передбачає врахування інтересів й досвіду жінок і чоловіків при розробці стратегій та заходів, при виконанні програм у різних сферах суспільного життя. Це дозволяє усунути жорсткі стандарти відносно жіночності та мужності, які виступають бар'єрами особистісної самореалізації. На думку сучасних науковців «гендерна рівність не передбачає нівелювання статі, але враховує в освітньому процесі специфіку життєвих інтересів та психологічних відмінностей дівчат і хлопців [2, с. 476-503]. Тобто імплементація гендерного підходу в освіту сприятиме відходу від концепції «вроджених статевих відмінностей між хлопчиками і дівчатами в освіті» та ідеї «вроджених статевих ролей», перенесе акцент на інституціональний контекст середовища і контекст взаємодії суб'єктів гендерних відносин [3, с. 109].

Під гендерною соціалізацією розуміємо процес засвоєння особистістю системи цінностей, норм, типів поведінки, стилю життя, соціальних ролей, що узгоджуються з культурними, соціальними, економічними, політичними контекстами буття та уявленнями про роль і місце чоловіка і жінки в суспільстві. Наслідком гендерної соціалізації індивіда є його долучення до гендерної культури, що забезпечує подолання ґендерної нерівності та досягнення ґендерного паритету як необхідної основи гармонізації суспільних відносин. На думку української соціологині та гендерної дослідниці Т. Марценюк [4, с. 33-42], соціальне засвоєння гендеру є тривалим процесом і відбувається в два етапи. На початковому (первинному) етапі ключову роль у набутті соціальних зв'язків особистості відіграє сімейне середовище як простір формування та практичного втілення маскулінних або фемінних моделей поведінки. Вторинна гендерна соціалізація особи триває впродовж всього її життя завдяки засвоєнню чоловічого і жіночого набору соціальних ролей та набуття нового соціального досвіду. Бачення світу крізь призму гендеру фрормує освіта соціальний інститут, що забезпечує в суспільстві дотримання принципів свободи, справедливості, відповідальності, егалітарності (рівності прав і можливостей), інклюзивності, толерантності, недискримінації.

Нагальною потребою сьогодення є вдосконалення організації та змісту навчально-виховного процесу на засадах гендерної рівності та недискримінації, що дозволить «не зводити реальне розмаїття хлопців/дівчат до однаковості типологій чоловіче/жіноче, а з розумінням ставитися до проявів варіативності (способи і стилі поведінки, захоплень, симпатій і антипатій, вибору та ін.), визнавати непереборність і цінність індивідуальності» [5, с. 29]. На думку вітчизняних науковців, впровадження гендерного підходу в навчально-виховний процес, сприятиме успішній соціалізації учнів та учениць, забезпечить максимальний розвиток їхніх особистих нахилів і здібностей без огляду на «закон статі», ...опанування дівчатами й хлопцями низки гендерних ролей, задля їх успішної соціальної адаптації у майбутньому» [6, с. 198].

Концептуальним є твердження: оскільки освіта має на меті всебічний особистісний розвиток, то вона має підстави і колосальні можливості щодо реалізації ідеї гендерної рівності, використання потенціалу гендерного виховання. Суб'єктами гендерного виховання є вихователі дошкільних навчальних закладів, вчителі-предметники, класні керівники, соціальні педагоги, психологи, керівники гуртків та секцій позашкільних навчальних закладів, викладачі ВН3, представники профрільного міністерства, управлінь відділів освіти та ін. Справедливе та рівне ставлення до дітей та молоді під час навчально-виховного процесу сприяє засвоєнню ними принципу егалітарності на безпосередніх прикладах, i, навпаки, упереджене ставлення до однієї з гендерних груп закріпляє уявлення про нерівні можливості.

Численні сучасні вітчизняні дослідження, на жаль, констатують «недружність» освітнього середовища до обох статей: упереджене ставлення до учнів та учениць, студентів і студенток за ознакою статі, наявність «прихованого» навчального плану з притаманною йому професійною 
горизонталлю та статусною вертикаллю у школі, негласним розподілом навчальних дисциплін на «жіночі» й «чоловічі», наявність гендерних стереотипів у підручниках, поведінці викладача, стилі навчання. Гендерна соціалізація молоді не можлива без подолання гендерних стереотипів, які заважають успішному розвитку особистості, обмежують життєве самовизначення вихованців і вихованок, закріплюють традиційні уявлення про призначення статей. «Будь-яка, навіть найпростіша, навчальна ситуація: вибір учителем або автором підручника прикладів, інтерпретація історичних подій, подання ілюстрацій, граматичних та синтаксичних конструкцій, - певним чином демонструють людині версію соціально-гендерного світу й стосунків у ньому» $[7$, с. 5$]$.

Впровадження гендерних підходів в освіті сприяє розвитку партнерських відносин між статями, виховує їх у дусі толерантності. Безпосередньо у вихованні гендерний підхід має на меті створення таких умов для виховання юнаків і дівчат, в яких їх «розвиток і духовно-ціннісна орієнтація будуть сприяти прояву і позитивному становленню індивідуальних маскулінних, фемінінних і андрогінних рис; відносно безболісному пристосуванню підростаючого покоління до реалій статево рольових відносин у суспільстві та ефрективному статево рольовому виокремленню в соціумі» [8, с. 115].

Сутність гендерного підходу в освіті полягає також в індивідуальному підході до прояву дитиною гендерної ідентичності. 3 позицій даного підходу, гендерна ідентичність не $є$ однаковою, жорсткою, однаковою для всіх чоловіків і жінок в рамках своєї статі, визнається індивідуальність, пластичність гендерних відмінностей. Це означає, що перед освітніми закладами постає завдання індивідуалізації гендерної ідентичності та вивчення суб'єктивних смислів створення тієї чи іншої моделі ідентичності кожним вихованцем. Як зазначає І. Костикова, «справа не в тому, що представники різних статей потребують диференційованого підходу з боку викладача, а в тому, що вони змушені стикатися зі складним світом мінливих гендерних стереотипів, які приходять у суперечність з особистими бажаннями і схильностями людини. Пояснити природу стереотипів, показати їх мінливість і соціальну обумовленість - такі завдання гендерного підходу в освіті» $[9$, с. 210$]$.

Важливим засобом впровадження ідеї гендерної рівності в освітній процес є антидискримінаційна експертиза навчальних програм та навчально-методичних комплексів. Результати гендерного аналізу навчально-методичного забезпечення нерідко свідчать про приховану дискримінацію, наявність стереотипів щодо соціальних ролей жінок та чоловіків, професійної діяльності і змісту праці. Внаслідок гендерного дисбалансу в молодого покоління формується уявлення, що саме чоловіки відіграють провідну роль у суспільстві та культурі; обмежуються знання учнів про відповідний внесок жінки і у суспільне життя, стереотипи в освітніх програмах більшою мірою заохочують до активності чоловіків, а жінок орієнтують на моделі поведінки, які мало співвідносяться з лідерством.

Ознакою гендерно нечутливого освітнього середовища є також гендерна стратифікація викладацької діяльності, яка проявляється в тому, що більшість зайнятих у цій сфері - жінки, але вони мають менш престижні та оплачувані посади, ніж керівний склад, представлений чоловіками.

Крайнім проявом гендерної дискримінації $€$ гендерно обумовлене насильство, що так само чиниться й в освітньому середовищі. Дані дослідження, проведеного в чотирьох областях України (Вінницькій, Київській, Черкаській і Чернігівській), свідчать про те,що найчастіше дівчата і хлопці зазнають насильства стосовно себе або знають про такі випадки стосовно друзів саме у школі. Причому дівчата більше страждають від психологічного насильства (образи, прізвиська, бойкотування), хоча відсоток здійснюваного щодо них фрізичного насилля (46\%) теж достатньо високий; хлопці часто зазнають двох видів насильства - психологічного і фрізичного [10, с. 18] Наведені дані також свідчать про несформовані механізми стримування фізичної агресії у молодого покоління, про недостатню увагу до таких ситуацій з боку оточуючих, а також про потребу популяризації асертивної (впевненої) поведінки, способів мирного розв'язання конфліктних ситуацій, толерантного ставлення один до одного.

Провідну роль у засвоєнні системи цінностей, норм, типів поведінки, стилю життя, соціальних ролей відіграє розвиток критичного мислення. Теоретичні і практичні підвалини критичної освіти заклав Пауло Фрейре, який обґрунтував, що в основі критичного мислення лежить розвиток особистості, котра завдяки проблемно-орієнтованій освіті навчається критично сприймати свою життєву ситуацію і осмислено трансформувати ії, у такий спосіб долаючи бідність та відсталість. 
За П. Фрейре, освіта - це інструмент національного розвитку, бо за її допомогою відбувається вивільнення творчих сил чоловіків і жінок для перетворення навколишнього світу [11, с. 54].

Для перетворення освіти на дієвий інструмент гендерної соціалізації молоді, необхідно вивчити чинники освітнього середовища, що впливають на процес формування гендерної ідентичності вихованців, форми навчально-виховної роботи, значимі для гендерної соціалізації, підготувати для цього педагогічних працівників. Розуміння гендерних проблем, оволодіння основними положеннями гендерної концепції стає актуальним завданням в сфері виховання та освіти молоді. Досягнення цієї мети вимагає корекції освіти та загальноосвітніх програм в школах, середніх спеціальних і вищих навчальних закладах, введення спеціальних курсів в систему підготовки педагогічних кадрів шкіл і вищих навчальних закладів, розробки гендерно-орієнтованих підручників для середньої школи, спрямованих на подолання стереотипних уявлень про соціальні ролі чоловіків і жінок, забезпечення науково-методичної бази. 3 погляду вікового аспекту гендерну освіту слід розглядати як освіту школярів, студентів, дорослих.

Освіта школярів має бути спрямована на те, щоб допомогти впоратися їм з проблемами соціалізації, важливою складовою частиною якої є ідентифікація дитини як хлопчика чи дівчинки і прийняття ними певної соціальної ролі. Освіта студентів будується на роз'ясненні гендерних стереотипів, з якими стикається молодь, вступаючи в доросле життя, і в спільному пошуку засобів подолання цих стереотипів. Освіта дорослих носить переважно адаптаційний характер, допомагаючи пристосуватися до суспільних змін та боротися з труднощами, що виникають.

Ініціаторами зміни гендерних відносин в освіті повинні стати викладачі вузів. Стиль викладання, фрорми комунікації в навчальній аудиторії також впливають на гендерну соціалізацію студентів. Скажімо, М. Дженкінс розробила поради для вузівських викладачів, які бажають створити атмосферу толерантності та рівноправності на своїх заняттях. 3 цією метою створений лист перевірки, який містить питання для самоаналізу лекцій і змісту курсу, що викладається, а також інтеракції в навчальній аудиторії [8, с. 187].

Ефективною у плані просування ідей гендерної рівності $є$ діяльність позанавчальних осередків гендерної освіти, які використовують інноваційні форми і методи роботи зі студентською молоддю. Зокрема, відповіддю на реальний суспільний запит щодо подолання будь-яких проявів явної чи прихованої дискримінації в практиках закладів вищої освіти стало створення Всеукраїнської мережі осередків гендерної освіти. За підтримки Мережі в 2015 році в Чернігівському національному технологічному університеті розпочав діяльність Центр гендерної освіти ЧНТУ. Центр координує свою роботу з Всеукраїнською мережею осередків гендерної освіти, яка розробляє сучасні методики і технології щодо впровадження гендерного компоненту в роботу 3 молоддю, як в навчальний, так і у виховний процес.

Основними напрямами діяльності Центру є: створення освітньо-виховними засобами умов для забезпечення рівних прав і можливостей жінок та чоловіків; ліквідація всіх форм дискримінації у суспільстві; попередження насильства; протидія торгівлі людьми; підготовка та проведення досліджень з питань гендерного становлення особистості; популяризація ідеї гендерної рівності, поширення гендерних знань та цінностей; проведення інформаційно-роз'яснювальної роботи з гендерних питань серед студентської молоді та викладачів вищого навчального закладу; підготовка інформаційних матеріалів з актуальних гендерних проблем сьогодення, підготовка соціальної реклами, шляхом залучення студентської молоді; підтримка громадських та державних просвітницьких гендерних ініціатив; співпраця з органами виконавчої влади та органами місцевого самоврядування, соціальними службами, іншими закладами освіти, підприємствами, об'єднаннями громадян, установами та організаціями, експертами з питань рівних прав та можливостей; активізація науково-дослідної роботи студентів та викладачів з гендерних питань; участь в організації та проведенні заходів різних рівнів (семінарів, конференцій, конгресів, форумів, круглих столів, конкурсів) з гендерної тематики; підготовка друкованих матеріалів (статті, навчально-методичні посібники, монографії) [12].

Волонтери центру реалізують громадські та державні просвітницькі гендерні ініціативи, здійснюють співпрацю з органами виконавчої влади та органами місцевого самоврядування, соціальними службами, іншими закладами освіти, підприємствами, об'єднаннями громадян, установами та організаціями, експертами з гендерної проблематики.

Члени осередку розробляють разом з викладачами та кураторами груп перспективні напрями та конкретні плани просвітницької і волонтерської діяльності, забезпечують координацію і 
комплексне проведення досліджень у співпраці з іншими науковими установами (організаціями), закладами освіти, соціальними службами тощо.

Висновок. Освітнє середовище є важливим чинником соціалізації особистості, адже воно формує її відношення до навколишнього світу, прав інших людей, їх самореалізації та свободи. Освіта, як соціальний інститут, сприяє самоідентифікації особистості, створює умови для засвоєння нею елементів культури, соціальних норм і цінностей, норм, типів поведінки, стилю життя, соціальних ролей на основі яких формуються соціально значущі риси особистості.

Аналіз чинників соціалізації особистості крізь призму гендерного підходу, дозволив дійти висновку, що фрормування гендерної ідентичності засобами освіти можливе за умови трансформації навчально-виховного процесу в напрямку нейтралізації гендерних стереотипів, подолання гендерної асиметрії та ієрархії в структурі освіти, створення умов для розвитку критичного мислення особистості.

Запорукою гендерної соціалізації особистості $€$ вдосконалення організації та змісту навчально-виховного процесу з урахуванням принципів свободи, справедливості, відповідальності, егалітарності (рівності прав і можливостей), інклюзивності, толерантності. Створення нового, гендерно чутливого освітнього середовища на засадах рівності та недискримінації дозволить забезпечити рівні права і можливості жінок та чоловіків, усунути бар'єри особистісної самореалізації та вивільнити творчі сили осіб обох статей.

\section{Література}

1. Ярская-Смирнова, Е. Р. Гендерное неравенство в образовании: понятие скрытого учебного плана / Е. Р. Ярская-Смирнова // Гендерные исследования. - 2000. - № 5. - С. 295-301.

2. Основи теорії гендеру: навчальний посібник / редакційна колегія посібника: Агеєва В. П., Кобелянська Л. С., Скорик М. М. - К. : К.І.С., 2004. - 536 с.

3. Штылёва, Л. В. Фактор пола в образовании: гендерный подход и анализ / Л. В. Штылёва. - М. : ПЕР СЭ, 2008. - 316 с.

4. Марценюк, Т. О. Ґендерна соціалізація як процес формування маскулінних та фемінних ознак ґендерної ідентичності / Т. О. Марценюк // Наукові записки НаУКМА : Соціологічні науки. - 2004. - Т. 32. - С. 33-42.

5. Петренко, О. Б. Гендерні підходи до освіти та виховання в історії вітчизняної школи і педагогіки (XX століття): автореф. дис. на здобуття наук. ступеня д. пед. наук: спец. 13.00 .01 Загальна педагогіка та історія педагогіки / О. Б. Петренко. - К., 2011. -43 с.

6. Дороніна, Т. О. Теоретико-методологічні засади гендерної освіти та виховання учнівської молоді : монографрія / Тетяна Олексіївна Дороніна ; НАПН, Інститут вищої освіти, КДПУ, МОНМС України. - Кривий Ріг : Видавничий дім, 2011. - $331 \mathrm{c}$.

7. Проблема гендерної нерівності в педагогічній освіті (Аналітична інформація за результатами «фокус-групового» соціально-психологічного дослідження). - К.: ПЦ “Фоліант”, 2003. - 59 с.

8. Социальная политика и социальная работа : гендерные аспекты: учебное пособие для студентов высших учебных заведений / под ред. Е. Р. Ярской- Смирновой. - М. : „Российская политическая энциклопедия” (РОССПЭН), 2004. - 292 с.

9. Агулина, С. В. Теоретические основы гендерного подхода в социальной педагогике / С. В. Агулина // Вестник Ставропольского государственного университета: серия „Педагогические науки”. - 2010. - № 71. - С. 210-219.

10. Дубровська, Є. Насильство в школі: аналіз проблеми та допомога, якої потребують діти та вчителі у ії розв'язанні / Є. Дубровська, М. Ясеновська, М. Алексєєнко. - К. : СП “Інтертехнодрук”, 2015. - 34 с.

11. Фрейре, П. Педагогіка пригноблених: пер. з англ. - К. : Юніверс, 2003. - 168 с.

12. Положення про Центр гендерної освіти Чернігівського національного технологічного університету [Електронний ресурс]. - Режим доступу: http://www.stu.cn.ua/staticpages/gender/.

\section{References}

1. Yarskaya-Smirnova, E. R. (2000). Gendernoe neravenstvo v obrazovanii: ponyatie skrytogo uchebnogo plana [Gender inequality in education: the concept of a hidden curriculum]. Gendernye issledovaniya - Gender Studies, 5, 295-301 [in Russian].

2. Aheieva, V. P., Kobelianska, L. S., Skoryk, M. M. (Eds.). (2004). Osnovy teorii henderu [Fundamentals of the gender theory]. Kyiv: K.I.S. [in Ukrainian].

3. Shtyleva, L. V. (2008). Faktor pola v obrazovanii: gendernyy podkhod $i$ analiz [Gender factor in education: gender approach and analysis]. Moscow: PER SE [in Russian].

4. Martseniuk, T. O. (2004). Genderna sotsializatsiia yak protses formuvannia maskulinnykh ta feminnykh oznak gendernoi identychnosti [Gender Socialization as a Process for the Formation of Masculine and Feminine Signs of Features Identity]. Naukovi zapysky NaUKMA: Sotsiolohichni nauky - Scientific notes of NaUKMA: Sociological sciences, 32, 33-42 [in Ukrainian].

5. Petrenko, O. B. (2011). Henderni pidkhody do osvity ta vykhovannia $v$ istorii vitchyznianoi shkoly i pedahohiky (XX stolittia) [Gender approaches to education and upbringing in the history of the native school and pedagogy (XX century)]. Extended abstract of candidate's thesis. Kyiv [in Ukrainian].

6. Doronina, T. O. (2011). Teoretyko-metodolohichni zasady hendernoi osvity ta vykhovannia uchnivskoi molodi [Theoretical and methodological principles of gender and student education]. Kryvyi Rih: Vydavnychyi dim [in Ukrainian].

7. Problema hendernoi nerivnosti $v$ pedahohichnii osviti (Analitychna informatsiia za rezultatamy "fokus-hrupovoho» sotsialno-psykholohichnoho doslidzhennia) [The problem of gender inequality in pedagogical education (Analytical information on the results of "focus group" socio-psychological study)]. (2003). Kyiv: PTs "Foliant" [in Ukrainian]. 
8. Yarskaya-Smirnova, E. R. (Eds.). (2004). Sotsialnaya politika i sotsialnaya rabota: gendernye aspekty [Social policy and social work: gender aspects]. Moscow: „Rossiyskaya politicheskaya entsiklopediya” (ROSSPEN) [in Russian].

9. Agulina, S. V. (2010). Teoreticheskie osnovy gendernogo podkhoda v sotsialnoy pedagogike [Theoretical foundations of gender approach in social pedagogy]. Vestnik Stavropolskogo gosudarstvennogo universiteta: seriya „Pedagogicheskie nauki" - Bulletin of Stavropol State University: "Pedagogical sciences” series, 71, $210-219$ [in Russian].

10. Dubrovska, Ye., Yasenovska, M., Aleksieienko, M. (2015). Nasylstvo v shkoli: analiz problemy ta dopomoha, yakoi potrebuiut dity ta vchyteli u yii rozviazanni [School violence: analysis of the problem and the help children and teachers requiring for its solving]. Kyiv: SP "Intertekhnodruk" [in Ukrainian].

11. Freire, P. (2003). Pedahohika pryhnoblenykh [Pedagogy of the oppressed]. Kyiv: Yunivers [in Ukrainian]

12. Polozhennia pro tsentr hendernoi osvity Chernihivskoho natsionalnoho tekhnolohichnoho universytetu [Center for Gender Education of Chernihiv National Technological University]. www.stu.cn.ua. Retrieved from https:// www.stu.cn.ua/staticpages/ gender/ [in Ukrainian].

Надійшла 13.11.2018

Бібліографічний опис для цитування :

Ємець, Н. А. Освітнє середовище як чинник гендерної соціалізації особистості / Н. А. Ємець, О. Є. Мельник, Н. В. Шакун // Проблеми соціальної роботи: філософрія, психологія, соціологія. - 2018 - № 2 (12) - С. $23-29$. 